\title{
Görsel Sanatlar Öğretmenlerinin Alternatif Değerlendirme Araçlarını Kullanabilme Özyeterlik Düzeylerinin Belirlenmesi
}

\section{Determining Visual Arts Teachers' Self-Efficacy Levels in Using Alternative Assessment Tools}

\author{
Sehran Dilmaç \\ Dr. Öğr. Üyesi, İzmir Katip Çelebi Üniversitesi Sanat ve Tasarım Fakültesi Temel Eğitim Bölümü \\ email: sehran.dilmac@ikcu.edu.tr (DORCID ID: https://orcid.org/0000-0003-4934-6048
}

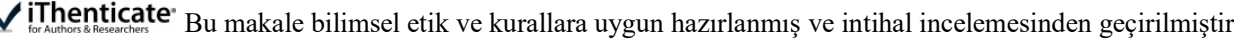

Atıf (APA 6)/To cite this article

Dilmaç, S. (2020). Görsel sanatlar öğretmenlerinin alternatif değerlendirme araçlarını kullanabilme özyeterlik düzeylerinin belirlenmesi. Atatürk Üniversitesi Güzel Sanatlar Enstitüsü Dergisi, 26(44), 138-149. doi: https://doi.org/10.35247/ataunigsed.657396

Makale Gönderim Tarihi/Received: 10/12/2019

Makale Kabul Tarihi/Accepted: 15/03/2020

Makale Yayın Tarihi/Published: 19/03/2020

Research Article / Araștırma Makalesi

\section{$\ddot{O} z$}

Bu çalıșma Görsel Sanat öğretmenlerinin alternatif değerlendirme araçlarını kullanabilmeye yönelik özyeterlik inançlarının saptanması amaciyla gerçekleștirilmiștir. Görsel sanatlar öğretmenlerinin alternatif değerlendirmeye ilişkin düşüncelerin belirlenmesi amacıyla yapılan bu araştırmada betimsel tarama yöntemi kullanılmıștır. Veriler Dilmaç (2013) tarafından geliştirilen "Görsel Sanat Öğretmenlerinin Alternatif Değerlendirme Araçlarını Kullanabilme Yeterlikleri Ölçeği" olarak adlandırılan Likert tipi bir ölçme aracı kullanılarak elde edilmiştir. Araştırmanın evrenini 2018-2019 öğretim yılında Erzurum'da görev yapan toplam 123 Görsel Sanatlar öğretmeni oluşturmaktadır. Uygulama sonucunda elde edilen verilere göre öğretmenlerin genelinin değerlendirme konusunda kendilerini yeterli gördükleri saptanmıştır. Bununla birlikte Eğitim Fakültesi mezunlarının Güzel Sanatlar Fakültelerinden mezun olmuş Görsel Sanatlar Öğretmenlerine göre alternatif değerlendirme araçları hakkında özyeterlik düzeylerinin daha yüksek olduğu belirlenmiștir.

Anahtar kelimeler: Görsel Sanat Eğitimi, Alternatif Değerlendirme, Değerlendirme

\begin{abstract}
The aim of this study is to determine the self-efficacy beliefs of Visual Art teachers about using alternative assessment tools. Descriptive scanning method was used in this research which was carried out to determine the thoughts related to alternative assessment of visual arts teachers. The data were obtained by using a Likert-type measurement tool named as "The Scale of Visual Art Teachers' Competence to Use Alternative Evaluation Tools" developed by Dilmaç (2013). The population of the research consists of 123 Visual Arts teachers working in Erzurum in the 2018-2019 academic year. According to the data obtained as a result of the application, it was determined that the teachers considered themselves sufficient in terms of evaluation. However, it was determined that the graduates of the Faculty of Education had higher self-efficacy levels about alternative assessment tools than Visual Arts Teachers who graduated from the Faculty of Fine Arts.
\end{abstract}

Keywords: Visual Arts Education, Alternative Assessment, Assessment

\section{Giriş}

Öğrenenlerin belirli bir program doğrultusunda duygu ve düşüncelerini farklı malzemelerle belirli tasarımlar yaparak iki veya üç boyutlu bir biçimde üretebildikleri bir süreç olan Görsel Sanatlar dersi öğrencinin algısal, estetiksel nitelikleri ile kendini ifade etme becerilerine olumlu etkisi vardır. Bu etkinin anlaşılabilmesi için öğrenenlerin sahip oldukları bilgi ve beceri düzeylerinin ve öğrenme süreçlerine ilişkin belirlenen öğrenme hedeflerinin gerçekleşme düzeylerini belirleyebilmek için sayısal verilere ihtiyaç duyulmaktadır. Buna imkan veren değerlendirme yaklaşımı olan alternatif değerlendirme yaklaşımları görsel sanatlar öğretimi için daha uygun değerlendirme yöntemlerini içeren bir yaklaşımdır. Çünkü Görsel Sanatlar dersi öncelikle performansa dayanan ve bu sürece ilişkin öğrencinin bilişsel özelliklerinin yanı sıra estetik ve yaratıcılığının gelişimini gözlemleme amacını taşıyan bir derstir (Eisner, 1997; Mamur, 2009; Walker, 1998).

Burada makalede vurgulanmak istenen husus konu içeriği hatırlamanın test edilmesi kolayken, eleştirel düşünme ve yaratıcılığın değerlendirilmesinin zor olduğudur. $\mathrm{Bu}$ nedenle alternatif değerlendirme araçlarına ve yöntemlerine ihtiyaç duyulmaktadır. Çünkü alternatif değerlendirme öğretmenlere, öğrencilerinin değişken durumlarda zayıf ve güçlü yanlarını anlama şansı vermenin yanı sıra sonuç odaklı bir değerlendirme yerine öğrencilerin aktif oldukları, performans temelli ve gerçek hayatla ilişkili bir sürecin değerlendirmeye alınması kazanımların daha doğru bir şekilde değerlendirilmesini sağlamaktadır (Mohamed \& Lebar, 2017). Dolayısıyla bu sürece ilişkin öğretmen görüşleri, değerlendirmeye ilişkin gerçekleştirilen uygulamalar hakkında bilgi vereceği düşünülmektedir. 
Son yıllarda yapılandırmacı yaklaşımla beraber okullarda, öğrencileri araştırmaya yönlendirerek, işbirliği, özgüven ve empatik yaklaşım gibi sosyal beceriler geliştirmeye yönelik etkinliklerin vurgulandığ yönlü olarak ele alındığı bir öğretim özendirilmiştir. Bu becerilerin geliştirilebilmesinde Görsel Sanatlar dersinin uyarıcı, özendirici ve geliştirici bir özelliği bulunmaktadır. Eleştirel düşünme, problem çözme, yaratıcılık ve araştırma gibi üst düzey zihinsel süreçleri harekete geçiren performans görevleri ve projeler gibi çalışmalar görsel sanatlar dersinde sıklıkla uygulanmaktadır. Bu üst düzey zihinsel süreçlerin geleneksel yöntemlerle sağlıklı bir biçimde ölçülmesi ve değerlendirilmesi mümkün değildir. Alternatif değerlendirme araçları ise zihinsel ve sanatsal süreçlerin daha sağlıklı ölçülmesinde eğitimcilere yardımcı olarak öğrencileri geleneksel araçların aksine eleştirel ve karmaşık problemlerle ilgili düşüncelerini düzenlemelerine yardım eder. Öğrenciler kısa cevaplar verirken veya geleneksel araçlardaki birden fazla seçenekten birini seçerken, alternatif araçlarla gerçek hayata kendi bakış açılarından cevaplar oluştururlar ve cevaplarını farklı şekillerde sunarlar (Ling, 2016; Herman, Klein \& Wakai, 1997). Geleneksel yöntemler genellikle ezberlenmiş bilgiyi değerlendirirken, alternatif değerlendirme araçları öğrencilerin kavrayışını ve başarısını ortaya çıkarmaya çalışır. Bu bağlamda, alternatif değerlendirme araçlarının farklı öğrenme stilleri olan öğrenciler için alternatif bir özelliği vardır ve bu öğrencilerin değerlendirilmesi için alternatifler sağlarlar (Llewellyn, 2003).

Geleneksel öğretim anlayışında öğrenmeyi değerlendirme etkinliği genellikle öğretimden ayrı olduğu düşünülerek sonuç odaklı sınavlarla gerçekleştirilir. Bu nedenle geleneksel değerlendirme yöntemi, bilgi ve becerileri ölçme konusunda gerçekten etkili değildir (Demir, Tananis \& Başboğaoğlu, 2018). Değerlendirme sürecinin yukarıda belirtildiği gibi geleneksel araç ve yöntemlerle sınırlı kalınması görsel sanatlar dersinin yapısal özelliği göz önüne alındığında bu ihtiyacı karşılamayacağı açıktır. En önemli amaçlarından biri öğrencinin yaratıcı düş gücünü artırmak olan görsel sanatlar dersinde hiçbir geleneksel değerlendirme aracı ile yaratıcılığı ölçmemiz mümkün değildir. "Geleneksel yöntemler genellikle öğrencileri düşündürerek onları araştırmaya yönelten etkinlikler şeklinde düzenlenmediği gibi bilgiyi kullanma, problem çözme, kısacası bilgiyi yeniden yapılandırma firsatları verilmediği için öğrenciler ezberledikleri yüzeysel bilgilerle mezun olmaktadır” (Açıkgöz, 2002, s. 63).

Sanat etkinlikleri bireyselliği ve özgünlüğü öne çıkaran kendine özgü birtakım özellikleri bünyesinde taşır. Bu nedenle geleneksel değerlendirme uygulamalarından farklı bir şekilde daha esnek, kapsamlı, farklı becerileri ölçebilen ve süreci de kapsayan alternatif değerlendirme araçlarına ihtiyaç duyulmaktadır. Çünkü sanat programlarının öğrencinin bilişsel ve duyuşsal gelişimine olan etkilerini anlayabilmek ve sanatsal yaratıcılık düzeylerini bir arada veya ayrı ayrı ölçmek karmaşık bir süreçtir (Armstrong, 1994; Beattie, 2000). Görsel Sanatlar dersinde diğer derslerde olduğu gibi tek bir doğru cevabın olmadığı öğrenci çalışmaları birkaç farklı değerlendirme aracı kullanılarak değerlendirilmesi daha doğru bir sonuç verecektir. Bu nedenle, performansa ve sürece odaklanarak öğrencilerin gerçek sorun çözme becerilerini ölçen alternatif değerlendirme yaklaşımından performans değerlendirme kullanılmalıdır (Tekin, 2019).

1990 yılından başlayarak öğrenci merkezli eğitim anlayışı çeşitli değerlendirme yöntem (performans değerlendirme, portfolyo değerlendirme, vb.) ve araçlarının (rubrik, kontrol listeleri, tutum ölçekleri, puanlama yönergeleri, vb.) kullanılmaya başlanmasına neden olmuştur (Gill \& Lucas, 2013; Sezer, 2005). Bu değerlendirme yöntem ve uygulamaları sanatsal öğrenmenin farklı boyutlarını ölçerek öğretmenlerin sanatsal öğrenme sürecine ilişkin daha doğru sonuçlar elde etmelerine yardımcı olmaktadır. Öğretmenlerin öğrencilerinin sanatsal üretimlerini değerlendirirken uygun alternatif değerlendirme araçlarını seçebilmesi de büyük bir önem taşımaktadır.

Literatürde alternatif değerlendirme yaklaşımlarının farklı disiplinlerde ve farklı konu alanlarında başarıyı arttırdığını gösteren çeşitli araştırmalar bulunmaktadır. Er (2018), çalışmasında alternatif değerlendirme aracı olarak kullandığı yapılandırılmış grid ve tanılayıcı dallanmış ağacı kapsayan uygulamalı araştırması sonucunda alternatif değerlendirmenin başarı ve tutum üzerine olumlu etkilerini ortaya koymuştur. Ayrıca alternatif değerlendirme yaklaşımlarının derslerin eğlenceli, anlaşılır ve ilgi çekici hale getirdiği, bu yöntemin dersi daha kolay anlamalarını ve öğrenmelerinde kalıcılık sağladığı bulgularına ulaşmıştır. Başoğlu'da (2017) alternatif değerlendirmenin akademik başarı üzerinde olumlu etkisinin olduğunu tespit etmiştir. Rivas ve Arrufat'1n (2016) alternatif değerlendirmede kullandıkları elektronik rubriklerin öğrenciler için öğretimde kaynağa ulaşmayı kolaylaştıran bir değerlendirme olduğu, öğrencilerin hem öz hem de akran değerlendirmelerinde kullanımlarından memnun oldukları, uygulama süreci ve öğrenme süreci üzerinde olumlu etkileri olduğu sonucuna ulaşmıştır. AlRuqeishi ve Al-Humaidi'nin (2016) gerçekleştirdikleri alternatif değerlendirmeye ilişkin öğretmen görüşlerini belirlemeye yönelik gerçekleştirdikleri araştırma sonucunda öğretmenlerin alternatif değerlendirmenin öğrencilerin öğrenmeleri hakkında farkındalıklarını geliştirdiklerini, öğretmenlerin değerlendirmeye ilişkin aldıkları eğitim ve desteği yeterli buldukları sonucuna ulaşmıştır.

Araştırmalar, görevlerin gerçek yaşam değerine sahip olduğu ve öğrencilerin gerçek dünyadaki görevleri gerçekleştirdiği zaman değerlendirmenin daha doğru sonuçlar verdiğini göstermektedir (Sewagegn \& Diale, 2020). Çünkü alternatif değerlendirme öğrencilerin öğrenmelerini artırmada büyük rol oynayarak onları çalışma alanlarında daha yetkin kılmaktadır. 
Gerçekleştirilen araştırmalarda öğretmenlerin öğretim programlarındaki ölçme değerlendirme araçlarını kullanma ve hazırlama konusunda bilgi eksikliklerinin olduğu ve eğitime gereksinim duyduklarını görmekteyiz (Gelbal ve Kelecioğlu, 2007; Mamur, 2009; Yapıcı ve Demirdelen, 2007). Bu durum öğretmenlerin özyeterlik düzeylerini ve eğitim ortamını da olumsuz etkileyecektir. Mojavezi ve Tamiz’in (2012), gerçekleştirdikleri öğretmen öz yeterlikleri ile öğrencilerin motivasyonu arasındaki ilişki ve başarıya olan etkisi konulu araştırma sonuçları buna göre öğretmen öz-yeterliliği ile öğrenci motivasyonu arasında olumlu bir ilişki olduğu belirlenmiştir.

Ölçme ve değerlendirme, öğretimde kullanılan materyallerin, yöntemlerin tekniklerin ve öğretim programlarının etkililiğini ortaya koyma, öğrenmenin hangi boyutta gerçekleştiğini anlama, öğretim için gerekli tedbirleri alma ve bir sonraki aşamayı planlama açısından önemlidir. Özellikle öğrenmenin kalitesi açısından kazanımların ne ölçüde gerçekleştiği ve öğrencilerin öğrenmede zorlandıkları alanların ve yanlış öğrenmelerin görülmesine yardımcı olmaktadır.

Değerlendirmede benimsenen yaklaşımın ve kullanılan yöntemlerin de önemi büyüktür. Değerlendirme ürün kadar sürecinde değerlendirmeye dahil edildiği bir anlayışına dayanmalıdır. Bu nedenle, sürecin sonunda öğrencinin ortaya koyduğu öğrenme ürünü ile birlikte süreç içerisinde gösterdiği performansın da değerlendirilmesi gerekmektedir. Fakat bu önerilerin dikkate alınarak alternatif değerlendirme yöntemlerinin kullanılmasını sağlamak için öğretmenlerde bu yöntemlerin faydalı olacağı ile ilgili bir inancın oluşturulması gerekmektedir. Böyle bir inancın oluşması içinde araştırmaların bu yöntemlerin diğer yöntemlerden farklı olarak öğrenmeye olan katkısını göstermesi ve maksimum düzeyde faydalanabilmenin koşullarını belirtmesi gerekmektedir.

$\mathrm{Bu}$ çalışmada alternatif değerlendirme yöntemlerine ilişkin görsel sanatlar öğretmenlerinin öz yeterlik düzeyleri belirlenmeye çalışılmıştır. Böylece öğretim programlarında bahsedilen alternatif yöntemlerinin etkililiğini ortaya koyarak eğitimcilere ve araştırmacılara bu konuda katkı sağlayacağı düşünülmektedir. Dolayısıyla öğretmen öz yeterlikleri konusunda yapılacak bu ve bunun gibi araştırmalar ilgili literatüre destek verecek çalışmalar olduğu ileri sürülebilir.

$\mathrm{Bu}$ kuramsal çerçeve 1şı̆̆ında araştırmanın problem cümlesini "Görsel Sanat öğretmenlerinin alternatif değerlendirme araçlarını kullanabilme yeterlik düzeyleri nedir? oluşturmaktadır. Araştırmanın alt problemleri ise şunlardır;

1.“Görsel Sanat öğretmenlerinin alternatif değerlendirme araçlarını kullanabilme yeterlik düzeyleri nedir?

2. Görsel Sanat öğretmenlerinin alternatif değerlendirme araçlarını kullanabilme yeterlik düzeyleri ile mezun oldukları fakülte değişkeni göz önüne alındığında bir farklılık oluşmakta mıdır?

3. Görsel Sanat öğretmenlerinin alternatif değerlendirme araçlarını kullanabilme yeterlik düzeyleri ile mesleki kıdem değişkeni göz önüne alındığında bir farklılık var mıdır?

\section{Yöntem}

$\mathrm{Bu}$ bölüm araştırmanın modeli, örneklem, veri toplama aracı, uygulama ve verilerin analizinde kullanılan tekniklere ilişkin açıklamaları içermektedir.

\subsection{Araştırmanın Modeli}

Görsel Sanatlar öğretmenlerinin değerlendirmeye ilişkin düşüncelerin saptanması sebebiyle yapılan bu araştırmada, betimsel tarama yöntemi uygulanmıştır. Verilere ulaşmada Dilmaç (2013) tarafindan geliştirilen Likert tipi bir ölçme aracı olarak tasarlanan "Görsel Sanat Öğretmenlerinin Alternatif Değerlendirme Araçlarını Kullanabilme Özyeterlik Ölçeği” uygulanmıştır.

\subsection{Evren ve Örneklem}

Bu araştırmanın evrenini 2018-2019 öğretim yılı bahar döneminde Erzurum il merkezi ve ilçelerinde görev yapmakta olan 123 görsel sanatlar öğretmeni oluşturmaktadır. Nicel gruba ilişkin bilgiler Tablo 1'de verilmiştir.

Tablo 1

Görsel Sanatlar Öğretmenlerine İlişkin Bilgiler

\begin{tabular}{lccc}
\hline Değişken & & $\mathbf{f}$ & $\mathbf{\%}$ \\
\hline & Kadın & 51 & 41 \\
Cinsiyet & Erkek & 72 & 59 \\
& Toplam & $\mathbf{1 2 3}$ & 100 \\
\hline \multirow{3}{*}{ Mezun olunan Fakülte } & Eğitim Fakülteleri & 92 & 74 \\
& Güzel Sanatlar Fakülteleri & 31 & 26 \\
& Toplam & $\mathbf{1 2 3}$ & 100 \\
\hline
\end{tabular}


Tablo 1'in devamı

\begin{tabular}{llcc}
\hline Değișken & & f & $\mathbf{\%}$ \\
\hline \multirow{3}{*}{ Mesleki Kıdem } & 1-5 Yı1l & 52 & 42 \\
& 6-10 Y1l & 39 & 32 \\
& 11 Y1l ve Üzeri & 32 & 26 \\
& Toplam & $\mathbf{1 2 3}$ & 100 \\
\hline
\end{tabular}

Tablo 1 incelendiğinde nicel grupta yer alan 123 Görsel Sanatlar öğretmeninden 51'i kadın (\%41), 72'si erkektir (\% 59); mezun olunan fakülte türü değişkenine göre görsel sanatlar öğretmenlerinden 92'si (\% 74) eğitim fakültesi (EF) mezunu, 31'i (\% 26) güzel sanatlar fakültesi (GSF) mezunudur; mesleki kıdem değişkeni bakımından ise görsel sanatlar öğretmenlerinden 52'si (\%42) 1-5 yıl mesleki kıdeme, 39'sı (\% 32) 6-10 yıl mesleki kıdeme ve 32 'si ise (\% 26) 11 yıl ve üzeri mesleki kıdeme sahip olduğu saptanmıştır.

\subsection{Veri Toplama Araçları}

Araştırmanın veri toplama aracı olarak Dilmaç (2013) tarafından geliştirilen "Görsel Sanat Öğretmenlerinin Alternatif Değerlendirme Araçlarını Kullanabilme Özyeterlik Ölçeği” kullanılmıştır. Araştırmada kullanılan veri toplama aracı aşağıda ayrıntılı biçimde tanıtılmıştır. Bu araştırmada, görsel sanat öğretmenlerinin ürün seçki dosyasına ilişkin öz yeterlik inançlarının saptanması ve değerlendirme hakkındaki görüşlerinin tespit edilmesi hedeflenmiştir. İlgili alanyazın taraması ve uzman görüşleriyle elde edilen veriler değerlendirilerek araştırmanın boyutu şekillendirilmiştir. Araştırma kapsamında görsel sanat öğretmenlerinin değerlendirmeye ilişkin öz yeterlik inançlarının saptanması için Dilmaç (2013) tarafından hazırlanan "Görsel Sanatlar Öğretmenlerinin gelişim dosyası, performans değerlendirme ve dereceli puanlama anahtarını kullanabilme yeterlikleri anketi" kullanılmıştır. Anket geliştirilmeden önce, performans değerlendirmenin ne olduğu görsel sanatlar eğitimindeki yeri hakkında geniş çağlı alanyazın araştırması yapılmıştır. Bu ankette, görsel sanatlar öğretmenlerinin ilerleme kayıt dosyası, başarım değerlendirme ve dereceli puanlama anahtarını kullanma yetilerini, ölçme araç ve yöntemlerinin kullanım tekrarlarını belirlemek hedeflenmiştir. Anket hazırlanırken, görsel sanatlar öğretmenlerinin ortaokul görsel sanatlar dersi programında var olan ölçme değerlendirme yöntemlerine dönük genel tutum ve düşünceleri toplanılmıştır. Görsel sanat öğretmenlerden toplanan görüşler ve gerçekleştirilen araştırmalar doğrultusunda toplam 52 maddelik bir anket oluşturulmuştur. Oluşturulan bu maddeler üzerinden uzman düşünceleri alınarak ankette yer edinmesi uygun düşenler belirlenmiştir. Başta 52 maddeden oluşan ankette, hedef doğrultusunda olmayan, birbiri ile aynı olan maddeler çıkarılarak 24 madde belirlenmiş ve ankete son nokta koyulmuştur. Oluşturulan bu anket, Türkiye'de gerekli izinler alınarak ilgili okullarda öğretmenlere bire bir uygulanmıştır. Oluşturulan anketin birinci kısmında, görsel sanatlar öğretmenlerinin mezun oldukları fakülteler, görev süreleri; İkinci kısımda, görsel sanatlar öğretmenlerinin ilerleme dosyası, performans değerlendirme ve dereceli puanlama anahtarı uygulayabilme yetilerini belirlemeye dönük olarak, "Tamamen katılıyorum, katılıyorum, orta derecede katılıyorum, katılmıyorum, tamamen katılmıyorum”, şeklinde likert tipi beşli derecelendirilmiş maddeler içermektedir. İlgili veriler SPSS 13.0 paket programında derinlemesine incelenmiştir. İncelemeler 1şı̆̆ında da; madde ortalamaları için t-testi sonuçları p $>0.05$ olan ve korelasyon katsayıları $\mathrm{r}<.30$ altta olan 27 madde ile madde toplam korelasyon değeri 0.30'dan aşağıda olan 1 madde de pilot ölçekten atılmıştır. Anketin Cronbach Alpha iç güvenirlik katsayısı ise, 0.92 olarak saptanmıştır.

\subsection{Verilerin Analizi}

Verilerin analizi sürecinde öncelikle verilerin parametrik testlerin varsayımları arasında yer alan "Veriler aralıklı veya orantısal olmalıdır.", "Veriler normal dağılıma uymalıdır." ve "Grup varyansları eşit olmalıdır" şeklindeki varsayımların karşılanıp karşılanmadığı kontrol edilmiştir. Örneklem grubundan elde edilen puanlarının normal dağılımını belirlemek için Shapiro-Wilk normallik testi ile basıklık-çarpıklık (kurtosis-skewness) değerleri irdelenmiş ve verilerin normal dağılmadığı ve bir takım değişkenlere ilişkin frekans değerlerinin 30'dan az olması nedeniyle parametrik olmayan testlerin yapılmasına karar verilmiştir. Parametik olmayan testlerden ise iki grubun kıyaslanmasında Mann Whitney U testi, ikiden fazla grubun kıyaslanmasında ise Kruskal Wallis Testinin kullanılmasına karar verilmiştir. Analiz sonuçları $\mathrm{p}<0.05$ anlamlılık düzeyinde test edilmiştir.

\section{Bulgular}

Araştırmanın bu bölümünde görsel sanatlar öğretmenlerinin alternatif değerlendirme araçlarını kullanabilme özyeterlik düzeylerine ilişkin analiz sonuçlarına ve görsel sanat öğretmenlerinin değerlendirmeye ilişkin görüşlerine yer verilmiştir.

\subsection{Birinci Alt Probleme İlişkin Bulgular}

Görsel sanatlar öğretmenlerinin ilerleme dosyası, başarım değerlendirme ve dereceli puanlama anahtarlarını kullanabilme yetilerine ilişkin betimleyici istatistikler Tablo 2.'de yer almaktadır. 
Tablo 2

Görsel Sanat Öğretmenlerinin Alternatif Değerlendirme Araçlarını Kullanabilme Özyeterlik Ölçeği Maddelerine İlişkin Betimleyici İstatistikler

\begin{tabular}{|c|c|c|c|c|c|c|c|c|c|c|c|c|}
\hline \multirow[t]{2}{*}{ Maddeler } & \multicolumn{2}{|c|}{ 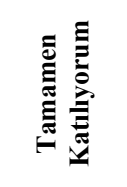 } & \multicolumn{2}{|c|}{ 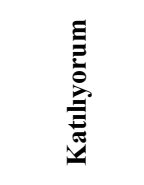 } & \multicolumn{2}{|c|}{ 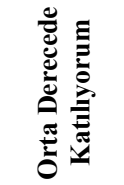 } & \multicolumn{2}{|c|}{ 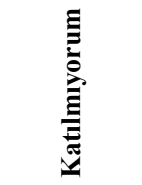 } & \multicolumn{2}{|c|}{ 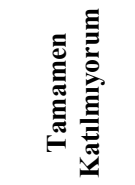 } & \multirow[t]{2}{*}{$\mathbf{X}$} & \multirow[t]{2}{*}{ SS } \\
\hline & f & $\%$ & f & $\%$ & f & $\%$ & f & $\%$ & f & $\%$ & & \\
\hline $\begin{array}{l}\text { 1.Değerlendirmede ürün dosyasını etkili olarak } \\
\text { kullanabiliyorum. }\end{array}$ & 7 & 6 & 8 & 7 & 24 & 19 & 59 & 48 & 25 & 20 & 3.76 & 1.14 \\
\hline $\begin{array}{l}\text { 2.Ürün dosyalarını kolay bir şekilde } \\
\text { değerlendirebiliyorum }\end{array}$ & 5 & 4 & 11 & 9 & 10 & 8 & 63 & 51 & 34 & 28 & 3.82 & 1.12 \\
\hline $\begin{array}{l}\text { 3.Ürün dosyalarının değerlendirilmesinde } \\
\text { uygun ölçütleri seçebiliyorum }\end{array}$ & 4 & 3 & 12 & 10 & 14 & 11 & 70 & 57 & 23 & 19 & 3.88 & .87 \\
\hline $\begin{array}{l}\text { 4.Ürün dosyalarının değerlendirilmesi } \\
\text { esnasında çok zaman harcıyorum }\end{array}$ & 23 & 19 & 48 & 38 & 31 & 25 & 13 & 11 & 8 & 7 & 3.54 & 1.17 \\
\hline $\begin{array}{l}\text { 5.Ürün dosyalarının değerlendirilmesinde bir } \\
\text { ölçme ve değerlendirme uzmanına ihtiyaç } \\
\text { duyuyorum. }\end{array}$ & 11 & 9 & 14 & 11 & 20 & 16 & 63 & 52 & 15 & 12 & 3.19 & 1.42 \\
\hline $\begin{array}{l}\text { 6.Ürün dosyası hakkında yeterli bilgiye } \\
\text { sahibim }\end{array}$ & 8 & 7 & 16 & 13 & 11 & 9 & 59 & 48 & 29 & 23 & 3.73 & 1.61 \\
\hline $\begin{array}{l}\text { 7.Ürün dosyasını sınıfımda etkili bir şekilde } \\
\text { kullanabiliyorum. }\end{array}$ & 9 & 7.5 & 15 & 12 & 16 & 13 & 58 & 47.5 & 25 & 20 & 3.75 & 1.12 \\
\hline $\begin{array}{l}\text { 8.Ürün dosyalarını değerlendirmede dereceli } \\
\text { puanlama anahtarını etkili bir şekilde } \\
\text { kullanabiliyorum }\end{array}$ & 26 & 21 & 62 & 50.5 & 19 & 15 & 7 & 6 & 9 & 7.5 & 2.82 & 1.83 \\
\hline $\begin{array}{l}\text { 9.Ürün dosyasına yönelik uygun dereceli } \\
\text { puanlama anahtarı hazırlayabiliyorum }\end{array}$ & 27 & 22 & 61 & 49 & 10 & 8 & 12 & 10 & 13 & 11 & 2.71 & 1.33 \\
\hline $\begin{array}{l}\text { 10.Ürün dosyasına yönelik uygun dereceli } \\
\text { puanlama anahtarı hazırlamak için ölçme ve } \\
\text { değerlendirme uzmanına ihtiyaç duyuyorum }\end{array}$ & 5 & 4 & 12 & 10 & 22 & 18 & 50 & 41 & 34 & 27 & 3.17 & 1.43 \\
\hline $\begin{array}{l}\text { 11.Öğrencilerin cinsiyetlerine uygun olarak } \\
\text { performans görevleri verebiliyorum }\end{array}$ & 9 & 7.5 & 12 & 10 & 10 & 8 & 60 & 48.5 & 32 & 26 & 3.91 & 1.15 \\
\hline $\begin{array}{l}\text { 12.Performans görevlerini öğrencilerin } \\
\text { seviyelerine uygun olarak verebiliyorum }\end{array}$ & 12 & 10 & 16 & 13 & 13 & 11 & 54 & 43 & 28 & 23 & 3.98 & .87 \\
\hline $\begin{array}{l}\text { 13.Öğrencilere, öğrencilerin üst düzey } \\
\text { düşünme becerilerini geliştirici performans } \\
\text { görevleri verebiliyorum }\end{array}$ & 5 & 4 & 11 & 9 & 21 & 17 & 58 & 48 & 28 & 22 & 1.99 & 1.28 \\
\hline $\begin{array}{l}\text { 14.Öğrencilerin performanslarını } \\
\text { değerlendirmek için onlara uygun ortamlar } \\
\text { hazırlayabiliyorum. }\end{array}$ & 23 & 19 & 44 & 36 & 26 & 21 & 20 & 16 & 10 & 8 & 3.92 & 1.11 \\
\hline $\begin{array}{l}15 . \text { Verdiğim performans görevleri birçok } \\
\text { beceriyi kapsiyor }\end{array}$ & 19 & 15 & 34 & 28 & 32 & 26 & 30 & 24 & 8 & 7 & 1.82 & 1.03 \\
\hline $\begin{array}{l}\text { 16.Performans görevlerini programda } \\
\text { belirtilen kazanıma uygun olarak } \\
\text { seçebiliyorum }\end{array}$ & 5 & 4 & 20 & 16 & 15 & 12 & 56 & 46 & 27 & 22 & 3.88 & 1.20 \\
\hline $\begin{array}{l}\text { 17.Performans görevlerini değerlendirmede } \\
\text { uygun ölçüt seçebiliyorum }\end{array}$ & 29 & 24 & 49 & 40 & 16 & 13 & 20 & 16 & 9 & 7 & 1.79 & 1.10 \\
\hline $\begin{array}{l}\text { 18.Programda bulunan kazanımların } \\
\text { değerlendirilmesinde zorlanıyorum. }\end{array}$ & 7 & 6 & 16 & 13 & 9 & 7 & 58 & 47 & 33 & 27 & 2.79 & 1.24 \\
\hline $\begin{array}{l}\text { 19.Performansların değerlendirilmesinde bir } \\
\text { ölçme ve değerlendirme uzmanına ihtiyaç } \\
\text { duyuyorum. }\end{array}$ & 10 & 8 & 13 & 11 & - & - & 70 & 57 & 30 & 24 & 3.81 & 1.38 \\
\hline $\begin{array}{l}20 . \text { Performans değerlendirme hakkında yeterli } \\
\text { bilgiye sahibim }\end{array}$ & 30 & 24 & 45 & 37 & 20 & 16 & 19 & 16 & 9 & 7 & 2.98 & .81 \\
\hline $\begin{array}{l}\text { 21.Performans değerlendirmeyi sınıf/atölye } \\
\text { içerisinde etkili bir şekilde kullanabiliyorum }\end{array}$ & 9 & 7 & 12 & 10 & 19 & 16 & 62 & 50 & 21 & 17 & 4.11 & 1.12 \\
\hline $\begin{array}{l}\text { 22.Performans değerlendirmede dereceli } \\
\text { puanlama anahtarını etkili bir şekilde } \\
\text { kullanabiliyorum. }\end{array}$ & 30 & 24 & 57 & 47 & 20 & 16 & 11 & 9 & 5 & 4 & 2.92 & 1.09 \\
\hline $\begin{array}{l}\text { 23.Dereceli puanlama anahtarı hakkında } \\
\text { yeterli bilgiye sahibim }\end{array}$ & 45 & 37 & 50 & 40 & 12 & 10 & 9 & 7 & 7 & 6 & 3.10 & 1.32 \\
\hline $\begin{array}{l}\text { 24. Dereceli puanlama anahtarı hazırlamak için } \\
\text { bir ölçme ve değerlendirme uzmanının } \\
\text { yardımına ihtiyaç duyuyorum. }\end{array}$ & 32 & 26 & 62 & 51 & 22 & 18 & 4 & 3 & 3 & 2 & 2.01 & 1.47 \\
\hline
\end{tabular}

Görsel sanatlar öğretmenlerinin alternatif değerlendirme araçlarını kullanabilme özyeterlik maddelerine ilişkin betimleyici istatistiklerinin verildiği Tablo 2. incelendiğinde öğretmenlerin değerlendirmede ürün dosyasını etkili olarak kullanabildikleri $(X=3.78)$, ürün dosyalarını kolay bir şekilde değerlendirebildikleri $(X=3.82)$, ürün dosyalarının değerlendirilmesinde uygun ölçütleri seçebildikleri $(X=3.88)$, ürün dosyası hakkında yeterli bilgiye 
sahip oldukları $(X=3.73)$, ürün dosyasını etkili bir şekilde kullanabildiklerini $(X=3.75)$, Ürün dosyasına yönelik uygun dereceli puanlama anahtarı hazırlamak için ölçme ve değerlendirme uzmanına ihtiyaç duymadıkları $(X=3.17)$, ögrencilerin cinsiyetlerine uygun olarak performans görevleri verebildikleri $(X=3.91)$, performans görevlerini öğrencilerin seviyelerine uygun olarak verebildikleri $(X=3.98)$, performans görevlerini programda belirtilen kazanıma uygun olarak seçebildikleri $(X=3.88)$, performansların değerlendirilmesinde bir ölçme ve değerlendirme uzmanına ihtiyaç duymadıkları $(X=3.81)$, performans değerlendirmeyi sınıf/atölye içerisinde etkili bir şekilde kullanabildiklerini ( $\mathrm{X}=4.11)$, öğrencilerin performanslarını değerlendirmek için onlara uygun ortamlar hazırlayabildiklerini $(X=3.92)$, dereceli puanlama anahtarı hakkında yeterli bilgiye sahip olduklarını $(X=3.10)$ ifade etmişlerdir.

Buna karşın ürün dosyalarının değerlendirilmesi esnasında çok zaman harcadıklarını $(\mathrm{X}=3.54)$, öğrencilere, öğrencilerin üst düzey düşünme becerilerini geliştirici performans görevleri veremedikleri $(X=1.99)$, verdikleri performans görevlerinin birçok beceriyi kapsamadığını $(X=1.82)$, performans görevlerini değerlendirmede uygun ölçüt seçmediklerini $(\mathrm{X}=1.79)$ ifade etmişlerdir.

\section{2.İkinci Alt probleme İlișkin Bulgular}

Görsel sanatlar öğretmenlerinin ilerleme dosyası, başarı değerlendirme ve dereceli puanlama anahtarlarını kullanabilme yeterlikleri maddelerine ilişkin görüşlerinin cinsiyet değişkenine göre farklılaşıp farklılaşmadığına ilişkin yapılan Mann Whitney U testi sonuçları Tablo 3'de yer almaktadır.

Tablo 3

Görsel Sanat Öğretmenlerinin Alternatif Değerlendirme Araçlarını Kullanabilme Yeterlikleri Ölçeği Maddelerine İlişkin Görüşlerinin Mezun Olunan Fakülte Değişkenine Göre Farklılaşma Durumu

\begin{tabular}{|c|c|c|c|c|c|c|c|}
\hline Maddeler & $\begin{array}{l}\text { Mezun } \\
\text { Olunan } \\
\text { Fakülte } \\
\end{array}$ & $\mathbf{N}$ & Sira Ort. & Sıra Toplamı & $\mathbf{U}$ & $\mathbf{Z}$ & $\mathbf{P}$ \\
\hline 1.Değerlendirmede ürün dosyasını & Eğitim F. & 92 & 63.12 & 4103.50 & \multirow{2}{*}{634.5} & \multirow{2}{*}{-2.325} & \multirow{2}{*}{.064} \\
\hline etkili olarak kullanabiliyorum. & Güzel San.F. & 31 & 32.19 & 971.50 & & & \\
\hline 2.Ürün dosyalarını kolay bir şekilde & Eğitim F. & 92 & 64.33 & 4139.50 & \multirow{2}{*}{612.5} & \multirow{2}{*}{-2.009} & \multirow{2}{*}{.027} \\
\hline değerlendirebiliyorum & Güzel San.F. & 31 & 48.48 & 923.50 & & & \\
\hline 3.Ürün dosyalarının & Eğitim F. & 92 & 51.12 & 4322.00 & \multirow[b]{2}{*}{701.0} & \multirow[b]{2}{*}{-1.992} & \multirow[b]{2}{*}{.058} \\
\hline $\begin{array}{l}\text { değerlendirilmesinde uygun } \\
\text { ölçütleri seçebiliyorum }\end{array}$ & Güzel San.F. & 31 & 42.96 & 859.10 & & & \\
\hline 4.Ürün dosyalarının & Eğitim F. & 92 & 56.09 & 4911.23 & \multirow[b]{2}{*}{891.2} & \multirow[b]{2}{*}{-2.322} & \multirow[b]{2}{*}{.984} \\
\hline $\begin{array}{l}\text { değerlendirilmesi esnasında çok } \\
\text { zaman harcıyorum }\end{array}$ & Güzel San.F. & 31 & 48.10 & 2345.50 & & & \\
\hline 5.Ürün dosyalarının & Eğitim F. & 92 & 42.10 & 4410.50 & \multirow[b]{2}{*}{740.5} & \multirow[b]{2}{*}{-2.420} & \multirow[b]{2}{*}{.078} \\
\hline $\begin{array}{l}\text { değerlendirilmesinde bir ölçme ve } \\
\text { değerlendirme uzmanına ihtiyaç } \\
\text { duyuyorum. }\end{array}$ & Güzel San.F. & 31 & 66.13 & 3305.50 & & & \\
\hline \multirow{2}{*}{$\begin{array}{l}\text { 6.Ürün dosyası hakkında yeterli } \\
\text { bilgiye sahibim }\end{array}$} & Eğitim F. & 92 & 63.17 & 4713.00 & \multirow{2}{*}{650.5} & \multirow{2}{*}{-2.130} & \multirow{2}{*}{.106} \\
\hline & Güzel San.F. & 31 & 43.64 & 1300.00 & & & \\
\hline \multirow{2}{*}{$\begin{array}{l}\text { 7.Ürün dosyasını sınıfımda etkili bir } \\
\text { şekilde kullanabiliyorum. }\end{array}$} & Eğitim F. & 92 & 63.29 & 4614.50 & \multirow{3}{*}{789.5} & \multirow{3}{*}{-1.599} & \multirow{3}{*}{.322} \\
\hline & Güzel San.F. & 31 & 55.10 & 1043.50 & & & \\
\hline \multirow{2}{*}{$\begin{array}{l}\text { 8.Ürün dosyalarını değerlendirmede } \\
\text { dereceli puanlama anahtarını etkili } \\
\text { bir şekilde kullanabiliyorum }\end{array}$} & Eğitim F. & 92 & 61.48 & 4312.50 & & & \\
\hline & Güzel San.F. & 31 & 34.01 & 1010.50 & 851.0 & -1.205 & .335 \\
\hline \multirow{2}{*}{$\begin{array}{l}\text { 9.Ürün dosyasına yönelik uygun } \\
\text { dereceli puanlama anahtarı } \\
\text { hazırlayabiliyorum }\end{array}$} & Eğitim F. & 92 & 57.99 & 4331.00 & \multirow[b]{2}{*}{689.0} & \multirow[b]{2}{*}{-2.634} & \multirow[b]{2}{*}{.056} \\
\hline & Güzel San.F. & 31 & 45.80 & 1245.00 & & & \\
\hline $\begin{array}{l}\text { 10.Ürün dosyasına yönelik uygun } \\
\text { dereceli puanlama anahtarı }\end{array}$ & Eğitim F. & 92 & 38.00 & 3934.00 & & & \\
\hline $\begin{array}{l}\text { hazırlamak için ölçme ve } \\
\text { değerlendirme uzmanına ihtiyaç } \\
\text { duyuyorum }\end{array}$ & Güzel San.F. & 31 & 68.10 & 1225.00 & 856.0 & -1.236 & .335 \\
\hline 11.Öğrencilerin cinsiyetlerine & Eğitim F. & 92 & 35.00 & 4012.78 & & & \\
\hline $\begin{array}{l}\text { uygun olarak performans görevleri } \\
\text { verebiliyorum }\end{array}$ & Güzel San.F. & 31 & 55.09 & 1278.50 & 566 & -804 & .000 \\
\hline 12.Performans görevlerini & Eğitim F. & 92 & 43.10 & 4256.00 & & & \\
\hline $\begin{array}{l}\text { öğrencilerin seviyelerine uygun } \\
\text { olarak verebiliyorum }\end{array}$ & Güzel San.F. & 31 & 53.57 & 1025.00 & 658.0 & -1.885 & .071 \\
\hline $\begin{array}{l}\text { 13.Öğrencilere, öğrencilerin üst } \\
\text { düzey düsünme becerilerini }\end{array}$ & Eğitim F. & 92 & 54.10 & 4244.00 & & & \\
\hline $\begin{array}{l}\text { geliştirici performans görevleri } \\
\text { verebiliyorum }\end{array}$ & Güzel San.F. & 31 & 44.56 & 1256.00 & 902.0 & -.598 & .680 \\
\hline 14.Öğrencilerin performanslarını & Eğitim F. & 92 & 55.36 & 4366.50 & & & \\
\hline $\begin{array}{l}\text { değerlendirmek için onlara uygun } \\
\text { ortamlar hazırlayabiliyorum. }\end{array}$ & Güzel San.F. & 31 & 49.33 & 1365.00 & 745.0 & -.854 & .654 \\
\hline
\end{tabular}


Tablo 3'ün devamı

\begin{tabular}{|c|c|c|c|c|c|c|c|}
\hline Maddeler & $\begin{array}{l}\text { Mezun } \\
\text { Olunan } \\
\text { Fakülte }\end{array}$ & $\mathbf{N}$ & Sira Ort. & Sira Toplamı & $\mathbf{U}$ & $\mathbf{Z}$ & $\mathbf{P}$ \\
\hline \multirow{4}{*}{$\begin{array}{l}\text { 15.Verdiğim performans görevleri } \\
\text { birçok beceriyi kapsıyor } \\
\text { 16.Performans görevlerini } \\
\text { programda belirtilen kazanıma } \\
\text { uygun olarak seçebiliyorum }\end{array}$} & Eğitim F. & 92 & 56.57 & 4325.50 & \multirow{3}{*}{854.5} & \multirow{3}{*}{-2.943} & \multirow{3}{*}{.262} \\
\hline & Güzel San.F. & 31 & 43.20 & 1523.50 & & & \\
\hline & Eğitim F. & 92 & 64.54 & 4102.00 & & & \\
\hline & Güzel San.F. & 31 & 57.00 & 1120.00 & 785.0 & -1.582 & .114 \\
\hline 17.Performans görevlerini & Eğitim F. & 92 & 63.11 & 4233.50 & \multirow[b]{2}{*}{713.5} & \multirow[b]{2}{*}{-1.557} & \multirow[b]{2}{*}{.223} \\
\hline $\begin{array}{l}\text { değerlendirmede uygun ölçüt } \\
\text { seçebiliyorum }\end{array}$ & Güzel San.F. & 31 & 35.95 & 895.50 & & & \\
\hline 18.Programda bulunan & Eğitim F. & 92 & 33.55 & 4102.00 & \multirow{3}{*}{741.0} & \multirow{3}{*}{-.945} & \multirow{3}{*}{.652} \\
\hline $\begin{array}{l}\text { kazanımların değerlendirilmesinde } \\
\text { zorlanıyorum. }\end{array}$ & Güzel San.F. & 31 & 56.15 & 2130.00 & & & \\
\hline 19.Performansların & Eğitim F. & 92 & 35.16 & 3856.00 & & & \\
\hline $\begin{array}{l}\text { değerlendirilmesinde bir ölçme ve } \\
\text { değerlendirme uzmanına ihtiyaç } \\
\text { duyuyorum. }\end{array}$ & Güzel San.F. & 31 & 61.50 & 2105.00 & 845.0 & -1.120 & .501 \\
\hline $\begin{array}{l}\text { 20.Performans değerlendirme } \\
\text { hakkında yeterli bilgive sahibim }\end{array}$ & $\begin{array}{l}\text { Eğitim F. } \\
\text { Güzel San.F. }\end{array}$ & $\begin{array}{l}92 \\
31\end{array}$ & $\begin{array}{l}53.20 \\
41.49\end{array}$ & $\begin{array}{c}4214.00 \\
854.00\end{array}$ & \multirow[t]{2}{*}{756.0} & \multirow[t]{2}{*}{-1.845} & \multirow[t]{2}{*}{.058} \\
\hline 21.Performans değerlendirmeyi & Eğitim F. & 92 & 56.13 & 4233.50 & & & \\
\hline $\begin{array}{l}\text { sinıf/atölye içerisinde etkili bir } \\
\text { şekilde kullanabiliyorum }\end{array}$ & Güzel San.F. & 31 & 44.23 & 845.50 & 564.5 & -1.856 & .068 \\
\hline 22.Performans değerlendirmede & Eğitim F. & 92 & 55.89 & 4102.00 & \multirow[b]{2}{*}{864.0} & \multirow[b]{2}{*}{-1.560} & \multirow[b]{2}{*}{.325} \\
\hline $\begin{array}{l}\text { dereceli puanlama anahtarını etkili } \\
\text { bir șekilde kullanabiliyorum. }\end{array}$ & Güzel San.F. & 31 & 48.50 & 956.00 & & & \\
\hline $\begin{array}{l}\text { 23.Dereceli puanlama anahtarı } \\
\text { hakkında yeterli bilgiye sahibim }\end{array}$ & $\begin{array}{l}\text { Eğitim F. } \\
\text { Güzel San.F. }\end{array}$ & $\begin{array}{r}92 \\
31\end{array}$ & $\begin{array}{l}56.21 \\
48.36\end{array}$ & $\begin{array}{l}4169.50 \\
1005.50\end{array}$ & \multirow[t]{2}{*}{851.5} & \multirow[t]{2}{*}{-1.256} & \multirow[t]{2}{*}{.65} \\
\hline 24.Dereceli puanlama anahtarı & Eğitim F. & 92 & 42.65 & 4684.00 & & & \\
\hline $\begin{array}{l}\text { hazırlamak için bir ölçme ve } \\
\text { değerlendirme uzmanının yardımına } \\
\text { ihtiyaç duyuyorum. }\end{array}$ & Güzel San.F. & 31 & 55.50 & 1236.00 & 895.0 & -.568 & .587 \\
\hline
\end{tabular}

Görsel sanatlar öğretmenlerinin alternatif değerlendirme araçlarını kullanabilme özyeterlik maddelerine ilişkin görüşlerinin mezun olunan fakülte değişkenine göre değişip değişmediğine ilişkin yapılan Mann Whitney Utesti sonuçları Tablo 3 incelendiğinde "Değerlendirmede ürün dosyasını etkili olarak kullanabiliyorum." maddesinde EF mezunu olan ögretmenlerin sıra ortalamaları (63.12) ile GSF mezunu öğretmenlerin sira ortalamaları (32.19) arasında anlamlı bir farklılık olduğu [(U=634.5, p<.05] ve bu farklılı̆̆ın ise EF mezunu öğretmenlerin lehine olduğu; "Ürün dosyalarını kolay bir şekilde değerlendirebiliyorum." maddesinde EF mezunu olan öğretmenlerin sıra ortalamaları (64.33) ile GSF mezunu öğretmenlerin sıra ortalamaları (48.48) arasında anlamlı bir farklılık olduğu $[(U=612.5, p<.05]$ ve bu farklılı̆ğn ise EF mezunu öğretmenlerin lehine olduğu; "Ürün dosyalarının değerlendirilmesinde uygun ölçütleri seçebiliyorum” maddesine EF mezunu olan öğretmenlerin sıra ortalamları (51.12) ile GSF mezunu öğretmenlerin sıra ortalamaları ( 42.96) arasında EF mezunu öğretmenlerin lehine anlamlı bir farklılık olduğu [(U= 701.0, p<.05]; "Ürün dosyalarının değerlendirilmesinde bir ölçme ve değerlendirme uzmanına ihtiyaç duyuyorum.." maddesinde EF mezunu olan öğretmenlerin sıra ortalamaları (42.10) ile GSF mezunu öğretmenlerin sıra ortalamaları (66.13) arasında anlamlı bir farklılık olduğu $[(\mathrm{U}=740.5, \mathrm{p}<.05]$ ve bu farklılığın ise GSF mezunu öğretmenlerin lehine olduğu; "Ürün dosyası hakkında yeterli bilgiye sahibim." maddesinde EF mezunu olan öğretmenlerin sıra ortalamaları (63.17) ile GSF mezunu öğretmenlerin sıra ortalamaları (43.64) arasında anlamlı bir farklılık olduğu $[(\mathrm{U}=650.5, \mathrm{p}<.05]$ ve bu farklılı̆̆ın ise EF mezunu öğretmenlerin lehine olduğu; "Ürün dosyasına yönelik uygun dereceli puanlama anahtarı hazırlayabiliyorum." maddesinde EF mezunu olan öğretmenlerin sıra ortalamaları (57.99) ile GSF mezunu öğretmenlerin sıra ortalamaları (45.80) arasında EF mezunu öğretmenlerin lehine anlamlı bir farklılık olduğu [(U=689.0, p<.05]; "Öğrencilerin cinsiyetlerine uygun olarak performans görevleri verebiliyorum." maddesinde EF mezunu olan öğretmenlerin sira ortalamaları (35.00) ile GSF mezunu öğretmenlerin sıra ortalamaları (55.09) arasında GSF mezunu öğretmenlerin lehine anlamlı bir farklılık olduğu $[(\mathrm{U}=566.0, \mathrm{p}<.05]$ anlaşılmaktadır.

\section{3.Üçüncü Alt Probleme İlişkin Bulgular}

Farklı mesleki kıdeme sahip görsel sanatlar öğretmenlerinin gelişim dosyası, performans değerlendirme ve dereceli puanlama anahtarlarını kullanabilme yeterlikleri maddelerine ilişkin görüşlerinin farklılaşıp farklılaşmadığına ilişkin yapılan Kruskal Wallis Testi sonuçları Tablo 4'de yer almaktadır. 
Tablo 4

Farklı Mesleki Kıdeme Sahip Görsel Sanatlar Öğretmenlerinin Alternatif Değerlendirme Araçlarını Kullanabilme Özyeterlikleri Ölçeği Maddelerine Kruskal Wallis Testi Sonuçları

\begin{tabular}{|c|c|c|c|c|c|c|c|}
\hline Maddeler & $\begin{array}{l}\text { Mesleki } \\
\text { Kıdem }\end{array}$ & $\mathbf{N}$ & Sira Ort. & $X^{2}$ & sd & $\mathbf{p}$ & Farklılık \\
\hline \multirow{3}{*}{$\begin{array}{l}\text { 1.Değerlendirmede ürün dosyasını } \\
\text { etkili olarak kullanabiliyorum. }\end{array}$} & $1-5$ Yil & 60 & 56.52 & \multirow{3}{*}{1.278} & \multirow{3}{*}{2} & \multirow{3}{*}{.657} & \\
\hline & 6-10 Y11 & 41 & 41.23 & & & & \\
\hline & 11 Yll ve Üzeri & 22 & 42.00 & & & & \\
\hline \multirow{3}{*}{$\begin{array}{l}\text { 2.Ürün dosyalarını kolay bir şekilde } \\
\text { değerlendirebiliyorum }\end{array}$} & 1-5 Yil & 60 & 55.53 & \multirow{3}{*}{.655} & \multirow{3}{*}{2} & \multirow{3}{*}{.897} & \\
\hline & 6-10 Y11 & 41 & 51.10 & & & & \\
\hline & 11 Y1l ve Üzeri & 22 & 46.00 & & & & \\
\hline 3.Ürün dosyalarının & 1-5 Yil & 60 & 54.78 & \multirow{3}{*}{2.349} & \multirow{3}{*}{2} & \multirow{3}{*}{.236} & \\
\hline değerlendirilmesinde uygun ölçütleri & 6-10 Yil & 41 & 40.36 & & & & \\
\hline seçebiliyorum & 11 Yil ve Üzeri & 22 & 56.70 & & & & \\
\hline \multirow{3}{*}{$\begin{array}{l}\text { 4.Ürün dosyalarının değerlendirilmesi } \\
\text { esnasında çok zaman harcıyorum }\end{array}$} & 1-5 Yil & 60 & 40.12 & \multirow{3}{*}{2.658} & \multirow{3}{*}{2} & \multirow{3}{*}{.365} & \\
\hline & 6-10 Y1l & 41 & 55.63 & & & & \\
\hline & 11 Y1l ve Üzeri & 22 & 60.63 & & & & \\
\hline \multirow{3}{*}{$\begin{array}{l}\text { 5.Ürün dosyalarının } \\
\text { değerlendirilmesinde bir ölçme ve } \\
\text { değerlendirme uzmanına ihtiyaç } \\
\text { duyuyorum. }\end{array}$} & 1-5 Yil & 60 & 44.69 & & & & \\
\hline & 6-10 Y11 & 41 & 43.75 & 5.120 & 2 & .085 & \\
\hline & 11 Yıl ve Üzeri & 22 & 63.40 & 5.120 & 2 & .085 & \\
\hline & $1-5$ Yil & 60 & 56.79 & & & & \\
\hline $\begin{array}{l}\text { 6. Urün dosyası hakkında yeterlı } \\
\text { bilgive sahibim }\end{array}$ & 6-10 Y11 & 41 & 43.18 & 2.364 & 2 & .540 & \\
\hline & 11 Y1l ve Üzeri & 22 & 41.18 & & & & \\
\hline 7 Ürün dosvasını sınıfimda etkili bir & 1-5 Y1l & 60 & 53.10 & & & & \\
\hline $\begin{array}{l}\text { 7.Urun dosyasinı sinifımda etkili bir } \\
\text { sekilde kullanabiliyorum. }\end{array}$ & 6-10 Y11 & 41 & 50.50 & .960 & 2 & .699 & \\
\hline & 11 Yil ve Üzeri & 22 & 49.53 & & & & \\
\hline 8.Ürün dosyalarını değerlendirmede & 1-5 Yil & 60 & 60.14 & & & & \\
\hline dereceli puanlama anahtarını etkili bir & 6-10 Y1l & 41 & 45.30 & 5.502 & 2 & .741 & \\
\hline şekilde kullanabiliyorum & 11 Yil ve Üzeri & 22 & 43.18 & & & & \\
\hline 9.Ürün dosyasına yönelik uygun & $1-5 Y_{11}$ & 60 & 61.18 & & & & \\
\hline dereceli puanlama anahtarı & 6-10 Yil & 41 & 55.94 & 4.632 & 2 & .165 & \\
\hline hazırlayabiliyorum & 11 Y1l ve Üzeri & 22 & 41.95 & & & & \\
\hline 10.Ürün dosyasına yönelik uygun & $1-5 Y_{11}$ & 60 & 55.36 & & & & \\
\hline dereceli puanlama anahtarı hazırlamak & $6-10 \mathrm{Y} 11$ & 41 & 59.56 & 2.653 & 2 & .365 & \\
\hline $\begin{array}{l}\text { için ölçme ve değerlendirme uzmanına } \\
\text { ihtiyaç duyuyorum }\end{array}$ & 11 Yıl ve Üzeri & 22 & 44.56 & 2.030 & 2 & .000 & \\
\hline 11.Öğrencilerin cinsiyetlerine uygun & $1-5 Y_{11}$ & 60 & 56.12 & & & & \\
\hline olarak performans görevleri & 6-10 Y1l & 41 & 47.89 & .974 & 2 & .489 & \\
\hline verebiliyorum. & 11 Y1l ve Üzeri & 22 & 51.50 & & & & \\
\hline 12.Performans görevlerini öğrencilerin & $1-5$ Yil & 60 & 43.47 & & & & \\
\hline seviyelerine uygun olarak & 6-10 Yil & 41 & 53.10 & 9.235 & 2 & .007 & Y1l ve $6-10$ Yil \\
\hline verebiliyorum. & 11 Yıl ve Üzeri & 22 & 61.47 & & & & \\
\hline 13.Öğrencilere, öğrencilerin üst düzey & 1-5 Yil & 60 & 41.26 & & & & 11 V11̈̈zori > 15 \\
\hline düşünme becerilerini geliştirici & 6-10 Y1l & 41 & 47.14 & 9.412 & 2 & .005 & 11 Y 1l uzeri $>1-5$ \\
\hline performans görevleri verebiliyorum. & 11 Yil ve Üzeri & 22 & 59.25 & & & & \\
\hline 14.Öğrencilerin performanslarını & $1-5 Y_{11}$ & 60 & 56.14 & & & & \\
\hline değerlendirmek için onlara uygun & 6-10 Y 11 & 41 & 50.75 & 1.742 & 2 & .568 & \\
\hline ortamlar hazırlayabiliyorum. & 11 Y1l ve Üzeri & 22 & 45.44 & & & & \\
\hline & $1-5$ Yil & 60 & 59.14 & & & & \\
\hline 15. Verdiğim performans görevleri & 6-10 Y1l & 41 & 41.36 & 9.815 & 2 & .009 & 1-5 Yil > 11 yil \\
\hline DırçoK Decerıyı Kapsıyor & 11 Y1l ve Üzeri & 22 & 46.10 & & & & \\
\hline 16.Performans görevlerini programda & 1-5 Y1l & 60 & 54.66 & & & & \\
\hline belirtilen kazanıma uygun olarak & 6-10 Y1l & 41 & 51.84 & 5.244 & 2 & 4.852 & \\
\hline seçebiliyorum & 11 Yil ve Üzeri & 22 & 48.56 & & & & \\
\hline 17.Performans görevlerini & 1-5 Yil & 60 & 59.25 & & & & \\
\hline değerlendirmede uygun ölçüt & 6-10 Y1l & 41 & 51.15 & 5.125 & 2 & .097 & \\
\hline seçebiliyorum & 11 Yil ve Üzeri & 22 & 46.10 & & & & \\
\hline & 1-5 Yil & 60 & 44.13 & & & & \\
\hline 18.Programda bulunan kazanımların & 6-10 Y1l & 41 & 51.20 & .962 & 2 & .741 & \\
\hline degerlendırılmesınde zorlanıyorum. & 11 Yil ve Üzeri & 22 & 56.30 & & & & \\
\hline 19.Performansların & 1-5 Yil & 60 & 50.18 & & & & \\
\hline değerlendirilmesinde bir ölçme ve & $6-10 Y_{11}$ & 41 & 61.14 & 3.365 & 2 & .568 & \\
\hline $\begin{array}{l}\text { değerlendirme uzmanına ihtiyaç } \\
\text { duyuyorum. }\end{array}$ & 11 Yıl ve Üzeri & 22 & 45.94 & 5.500 & 2 & .000 & \\
\hline $\begin{array}{l}\text { 20.Performans değerlendirme hakkında } \\
\text { yeterli bilgiye sahibim }\end{array}$ & $\begin{array}{c}\text { 1-5 Yil } \\
6-10 \text { Yil } \\
11 \text { Yil ve Üzeri }\end{array}$ & $\begin{array}{l}60 \\
41 \\
22\end{array}$ & $\begin{array}{l}56.18 \\
50.46 \\
43.75 \\
\end{array}$ & 1.125 & 2 & .658 & \\
\hline
\end{tabular}


Tablo 4'ün devamı

\begin{tabular}{|c|c|c|c|c|c|c|c|}
\hline Maddeler & $\begin{array}{l}\text { Mesleki } \\
\text { Kıdem }\end{array}$ & $\mathbf{N}$ & Sira Ort. & $X^{2}$ & sd & $\mathbf{p}$ & Farklılık \\
\hline 21.Performans değerlendirmeyi & $1-5$ Yil & 60 & 61.56 & \multirow{3}{*}{9.452} & \multirow{3}{*}{2} & \multirow{3}{*}{.008} & \multirow{11}{*}{$\begin{array}{c}1-5 \text { Y1l > } 11 \text { yıl } \\
\text { ve üzeri }\end{array}$} \\
\hline sınıf/atölye içerisinde etkili bir şekilde & 6-10 Y11 & 41 & 47.15 & & & & \\
\hline kullanabiliyorum & 11 Yil ve Üzeri & 22 & 41.16 & & & & \\
\hline 22.Performans değerlendirmede & $1-5$ Y 11 & 60 & 55.18 & \multirow{3}{*}{4.471} & \multirow{3}{*}{2} & \multirow{3}{*}{.098} & \\
\hline dereceli puanlama anahtarını etkili bir & $6-10 Y_{11}$ & 41 & 47.63 & & & & \\
\hline şekilde kullanabiliyorum. & 11 Y1l ve Üzeri & 22 & 41.62 & & & & \\
\hline 23.Dereceli puanlama anahtarı & 1-5 Yil & 60 & 51.25 & \multirow[b]{2}{*}{.106} & \multirow{2}{*}{2} & \multirow{2}{*}{.180} & \\
\hline hakkında yeterli bilgiye sahibim & $\begin{array}{l}\text { 6-10 Yil } \\
11 \text { Y1l ve Üzeri }\end{array}$ & $\begin{array}{l}41 \\
22\end{array}$ & $\begin{array}{l}53.14 \\
50.96\end{array}$ & & & & \\
\hline 24.Dereceli puanlama anahtarı & 1-5 Yil & 60 & 55.76 & \multirow{3}{*}{1.520} & \multirow{3}{*}{2} & \multirow{3}{*}{.175} & \\
\hline hazırlamak için bir ölçme ve & 6-10 Y11 & 41 & 53.65 & & & & \\
\hline $\begin{array}{l}\text { degerlendırme uzmanının yardımına } \\
\text { ihtiyaç duyuyorum. }\end{array}$ & 11 Y1l ve Üzeri & 22 & 52.36 & & & & \\
\hline
\end{tabular}

Farklı mesleki kıdeme sahip görsel sanatlar öğretmenlerinin alternatif değerlendirme araçlarını kullanabilme özyeterlik maddelerine ilişkin görüşlerinin farklılaşıp farklılaşmadığını test etmek için Kruskal Wallis Testi yapılmış ve "Performans görevlerini öğrencilerin seviyelerine uygun olarak verebiliyorum $\left(X^{2}(2)=9.235\right.$, p<.05).”, “Öğrencilere, öğrencilerin üst düzey düşünme becerilerini geliştirici performans görevleri verebiliyorum, $\left(X^{2}(2)=9.412, \mathrm{p}<.05\right)$.", "Verdiğim performans görevleri birçok beceriyi kapsiyor, $\left(X^{2}(2)=9.815\right.$, p<.05).", Performans değerlendirmeyi sınıf/atölye içerisinde etkili bir şekilde kullanabiliyorum $\left(X^{2}(2)=9.453\right.$, p<.05).maddelerinde grupların sıra ortalamaları arasında anlamlı farklılık olduğu gözlenmiştir. Farklılığın hangi grup lehine olduğunu belirlemek için yapılan Mann Whitney U testi sonuçlarına göre bu farklılığın ilgili 12 ve 13 . maddelerde 11 yıl ve üzeri mesleki kıdeme sahip öğretmenlerin lehine, 15 ve 21 . Maddelerde ise 1-5 yıl kıdeme sahip öğretmenlerin lehine olduğu tespit edilmiştir.

\section{Sonuç ve Tartışma}

Alternatif ölçme-değerlendirme yöntemleri kullanmanın asıl amacı, geleneksel ölçme-değerlendirme yöntemleri ile ölçülemeyecek becerilerin bu yöntemlerle ölçülmesidir. Gerçek yaşama yönelik görevler değerlendirildiğinden otantik öğrenmelere ve değerlendirmelere olanak sağlar. Alternatif ölçme-değerlendirme yöntemlerinin sınıf içinde kullanılmasının sebebi, öğrencilerin ne yaptıklarının değil, neler yapabileceklerinin ortaya çıkarılmasıdır. $\mathrm{Bu}$ tür tekniklerin kullanımında öğrencilerin yeteneklerini sergilemeleri, anlamlı bir görev gerçekleştirmeleri gerekmektedir. Kısacası öğrenciden öğrenme hedeflerine uygun bir şekilde karmaşık bir görevi yapması ve bunun değerlendirilmesi alternatif ölçme-değerlendirme yöntemlerinin amacıdır. Tipik alternatif ölçme-değerlendirme araçları portfolyolar, proje ödevleri ve genellikle rubriklerin kullanıldığı bazı etkinliklerdir.

Görsel sanatlar öğretmenlerinin alternatif değerlendirme araçlarını kullanabilme özyeterlik maddelerine ilişkin betimleyici istatistikler incelendiğinde birinci alt probleme ilişkin elde edilen bulgulara dayanarak şu sonuçlara varılmıştır; Görsel sanat öğretmenleri değerlendirmede ürün dosyasını etkili olarak kullandıkları, ürün dosyalarını kolay bir şekilde değerlendirdikleri, ürün dosyalarının değerlendirilmesinde uygun ölçütleri seçebildikleri, ürün dosyası hakkında yeterli bilgiye sahip oldukları, ürün dosyasını sınıfında etkili bir şekilde kullanabildikleri, ürün dosyalarını değerlendirmede dereceli puanlama anahtarını nitelikli bir şekilde kullanabildikleri, ürün dosyasına yönelik uygun dereceli puanlama anahtarı hazırlayabildikleri, öğrencilerin cinsiyetlerine uygun olarak performans görevleri verebildikleri ve performans görevlerini öğrencilerin seviyelerine uygun olarak verebildikleri yönünde kendilerini yeterli görmektedirler. Buna karşın ürün dosyalarının değerlendirilmesi esnasında çok zaman harcadıkları, öğrencilerin üst düzey düşünme becerilerini geliştirici performans görevleri veremedikleri, verdikleri performans görevlerinin birçok beceriyi kapsamadığı, performans görevlerini değerlendirmede uygun ölçüt seçemedikleri belirlenmiştir. Öğretmenlerin her ne kadar azda olsa ifade ettikleri olumsuz düşünceleri ise mesleki eğitim süreçleri boyunca yeterli düzeyde değerlendirmeye yönelik eğitim almamalarından kaynaklanıyor olabilir. Baker (2010) öğretmenlerin alternatif ölçme-değerlendirmeye uygun öğretim için eğitim almadıklarından zorlandıklarını belirtmesi bu düşünceyi doğrulamaktadır. Genel olarak araştırma sonunda elde edilen veriler ışığında, öğrenci başarısının tek bir yönteme bağlı kalınarak ölçülmesi yerine alternatif değerlendirme yöntemlerini içerecek şekilde farklı yöntemlerle ölçülmesine olan inancın ve öğretmenlerin konuya ilişkin özyeterlik düzeylerinin yüksek olduğu görülmektedir. Elde edilen bu sonuçlar Huff’un (2006) portfolyo oluşturma sürecine ilişkin öğretmen görüşlerini incelediği araştırmasının sonuçlarından farklıdır. Huff araştırması sonucunda öğretmenlerin portfolyoyu hem değerlendirme hem de mesleki gelişimde kullanmanın onları zihinsel olarak yorduğu ve özyeterlik düzeylerini olumsuz etkilediği sonucunu elde etmiştir. Buna karşı Duran, Mıhladız ve Ballıel'in (2014), Güneş, Dilek, Hoplan, Çelikoğlu ve Demir'in (2010) ve İzci, Göktaş ve Süleyman'ın (2014) elde etmiş oldukları sonuçlar gerçekleştirilen bu araştırma ile benzerlik göstermektedir. Kilmen ve Kösteroğlu'nun (2017) gerçekleştirdikleri öğretmenlerin alternatif değerlendirmeye ilişkin görüşlerini inceledikleri araştırma bulgularına göre de öğretmenlerin yarısından fazlası tamamlayıcı değerlendirme yaklaşımlarını yararlı, önemli, 
gerekli bulmakta ve öğrencilere kendilerini değerlendirme firsatı verdiğini düşünmektedirler. Bu çalışmalarda öğrencilerin alternatif değerlendirmeye yönelik olumlu tutum geliştirerek yeterlilik algılarının artmış olması nedeniyle bu tekniklerden yüksek puanlar almış olabilirler. Bu çalışmanın sonuçlarıyla uyumlu olarak, Oluk ve Ekmekçi’nin (2017) alternatif değerlendirme teknikleri ile klasik tekniklerin öğrenci başarısını ölçme etkinliklerini karşılaştırdığ çalışmasında alternatif değerlendirme teknikleri ile geleneksel değerlendirme teknikleri arasında anlamlı bir fark bulmuş ve farkın alternatif tekniklerden yana olduğunu ortaya koymuştur. Alternatif değerlendirme özellikle öğretim sürecinde öğrenci performansının değerlendirilmesine odaklanır. Dolayısıyla performans değerlendirmeleri, öğrencilerin karmaşık veya önemli görevleri aktif olarak yerine getirirken gerçekçi, özgün problemleri çözmek için önceden bilgi, son öğrenme ve ilgili beceriler geliştirmelerini gerektiren değerlendirmeler olduğu için gerçekleştirilen araştırma sonuçlarını olumlu yönde etkilemiş olduğu düşünülebilir. ABD ve Türkiye'de öğretmenlerin alternatif değerlendirme araçlarına ilişkin görüşlerinin karşılaştırıldığı araştırma sonuçları da bu sonuçları desteklemektedir (Demir vd, 2018). Özellikle ABD'de görev yapan öğretmenlerin de benzer şekilde alternatif değerlendirme araçlarını kullanırken öğrencileri bilgilendirmede, zamanı etkin kullanabilmede sıkıntılar yaşadıklarını ifade etmişlerdir. Oliver'da (2015), alternatif değerlendirmenin uygulanmasının yoğun ve zaman alıcı olduğunu belirtmektedir. Ozan (2019) tarafından gerçekleştirilen otantik değerlendirmenin akademik başarı ve eğitim ölçümüne yönelik tutum ve öğretmen adaylarının görüşlerine etkisi başlıklı araştırma sonuçları otantik değerlendirmenin, öğretmen adaylarının eğitimsel ölçümüne yönelik akademik başarısını ve tutumunu önemli ölçüde artırdığı ve ayrıca Türkiye'de öğretmen eğitimi alanında önemli bir sorun olan teori ve uygulama arasında işbirliği sağlanmasına yardımcı olabilecek bir yaklaşım olduğu belirlenmiştir.

Mezun olunan fakülte değişkenine ilişkin yeterlik düzeyleri incelendiğinde ikinci alt probleme ilişkin elde edilen bulgulara dayanarak şu sonuçlara varılabilir; Eğitim Fakültesi mezunu öğretmenlerin Güzel Sanatlar Fakültesi mezunu öğretmenlere göre değerlendirmede ürün dosyasını etkili olarak kullandığı, ürün dosyalarını kolay bir şekilde değerlendirdiği, ürün dosyası hakkında yeterli bilgiye sahip olduğu, ürün dosyasına yönelik uygun dereceli puanlama anahtarı hazırlayabildiği, performans, dereceli puanlama anahtarı ve ürün dosyalarının değerlendirilmesinde bir ölçme ve değerlendirme uzmanına daha az ihtiyaç duydukları, performans değerlendirmede dereceli puanlama anahtarını etkili bir şekilde kullanabildikleri belirlenirken, Güzel Sanatlar Fakültesi mezunu öğretmenlerin Eğitim Fakültesi mezunu öğretmenlere göre öğrencilerin cinsiyetlerine uygun olarak performans görevleri verebildiklerini ve performans görevlerini öğrencilerin seviyelerine uygun olarak verebildikleri şeklinde sonuçlandırılmıştır. Yapılandırmacı yaklaşımda ortaya çıkan alternatif değerlendirme tekniklerinin öğretmenlere ortam düzenleme, tasarlama, yönlendirme gibi roller yüklemektedir (Mamur, 2009; Yurdakul, 2004). Dolayısıyla eğitim fakültesinde öğrenim görmüş olan öğretmenlerin lisans eğitimleri sürecinde yapılandırmacı yaklaşım uygulamaları ile daha fazla karşılaşmış olmaları ve bunu meslek hayatlarında uygulamalarından kaynaklanmış olabilir. Karamustafaoğlu, Çağlak ve Meşeci’nin (2012) sınıf öğretmenlerinin alternatif ölçme değerlendirme araçlarına ilişkin öz yeterliklerini belirlemek amacı ile gerçekleştirdikleri araştırmada elde ettikleri sonuçlar bu bulguyu destekler niteliktedir. Yapmış oldukları araştırma sonucu incelendiğinde eğitim fakültesi mezunu öğretmenlerin diğer fakülte mezunu öğretmenlere göre daha yüksek bir ortalamaya sahip oldukları görülmektedir.

Mesleki kıdem değişkenine göre öğretmenlerin yeterlik düzeyleri incelendiğinde üçüncü alt probleme ilişkin elde edilen bulgulara dayanarak şu sonuçlara varılabilir; Gerçekleştirilen analiz sonuçları incelendiğinde öğretmenlerin alternatif değerlendirme araçlarını kullanma yeterlik düzeyleri anketinde 22 maddede mesleki kıdem değişkeni göz önüne alındığında farklılık göstermediği belirlenmiştir. Şahin ve Atasoy’un (2018) öğretmenlerinin alternatif değerlendirme yöntemlerine yönelik tutumlarını kıdem değişkenine göre inceledikleri araştırma sonucuna göre kıdemin öğretmenlerin alternatif değerlendirme yöntemlerine yönelik tutumlarında belirleyici olmadığı görülmüştür. $\mathrm{Bu}$ bulgu araştırmada da elde edilen bulguları destekler niteliktedir. Buna karşın anketin dört maddesinde ise anlamlı farklılıklar olduğu saptanmıştır. Buna göre; 1 ile 5 yıllık meslek tecrübesine sahip görsel sanat öğretmenlerinin 6 yıl ve üzeri yıllık meslek tecrübesine sahip öğretmenlere nazaran verdikleri performans görevlerinin birçok beceriyi kapsadığını ve öğrencilere, öğrencilerin üst düzey düşünme becerilerini geliştirici performans görevleri verebildikleri, 11 yıl ve üstü mesleki kıdeme sahip öğretmenlerin de 1 ile 10 yıl arasında mesleki kıdeme sahip öğretmenlere göre verdikleri performans görevlerinin birçok beceriyi kapsadı̆̆ını, performans değerlendirmeyi sınıf/atölye içerisinde etkili bir şekilde kullanabildiklerini sonucuna ulaşılmıştır.

Bu sonuçlar 1şı̆̆ında 1 ile 5 yıllık mesleki deneyime sahip öğretmenlerin mesleğe başlayabilmeleri için gerekli olan KPSS sınavına (Türkiye'de öğretmen olabilmek için girilen sınav) hazırlanma süreçlerinde ölçme değerlendirme konularını yakın tarihlerde içselleştirdikleri için 15. ve 21. maddelerde kendilerini daha yeterli görmüş olmalarına neden olmuş olabilir. Bunun yanı sıra 12. ve 13. maddelerde ise mesleki kıdemi 1 yıl ve daha üstü öğretmenlerin olması mesleki deneyimin performans belirlemede ve etkin bir şekilde kullanılmasında olumlu bir etkisi olduğu ileri sürülebilir. 
Bu sonuçlar 1şı̆̆ında şu önerilerde bulunulabilir.

- Türkiye’de öğretmen yetiştirme kaynakları yeniden gözden geçirilmeli,

- Öğretmen yetiştirme lisans programlarında gerekli uygulamaların artırılması sağlanmalı,

- Öğretmenlere mesleki hizmet içi kurslarında gerekli uygulamaları gerçekleştirebilecekleri uygun ortamlar hazirlamal1,

- Öğretmenlerin gerektiğinde başvuracakları ölçme değerlendirme uzmanları görevlendirilmelidir.

\section{Kaynakça}

Açıkgöz, K. (2002). Aktif öğrenme. İzmir: Eğitim Dünyası Yayınları.

Al-Ruqeishi, M., \& Al-Humaidi, S. (2016). Alternative Assessment as Perceived by EFL Teachers. IUP Journal of English Studies, 11(3), 88-101. Erişim adresi: https://squ.pure.elsevier.com/en/publications/alternativeassessment-as-perceived-by-efl-teachers

Armstrong, C. (1994). Designing assessment in art. Reston: NAEA.

Baker, E. L. (2010). What probably works in alternative assessment (Rapor No. CRESST Report 772). California, Los Angeles: National Center for Research on Evaluation, Standards, and Student Testing. Erişim adresi: http://files.eric.ed.gov/fulltext/ED512658.pdf

Başoğlu, S. (2017). Klasik ve teknoloji destekli tanılayıcı dallanmış ağaç tekniğinin öğrencilerin akademik başarılarına, kavram yanılgılarına ve bilişsel yüklerine etkisi (Doktora tezi). YÖK Tez veri tabanından erişildi. (Tez No. 494991)

Beattie, D. K. (2000). Creativity in art: The feasibility of assessing currentconceptions in the school context. Assessment in Education: Principles, Policy \& Practice, 7(2),175-192. doi: 10.1080/713613331

Demir, M., Tananis, C. A., \& Başboğaoğlu, U. (2018). Comparative investigation of alternative assessment methods used in Turkey and United States elementary 4th grade mathematics curriculum. International Journal of Educational Administration and Policy Studies. 10(7). 72-82. doi: https://doi.org/10.5897/IJEAPS2018.0561

Dilmaç, O. (2013). The competences of visual arts teachers in using performance evaluation methods: The case of Turkey. A. Karpati and E. Gaul. (Ed.), In From child art to visual language of youth (101-116). UK: Intellect, The University of Chicago Press.

Duran, M., Mıhladız, G., \& Ballıel, B. (2014). İlköğretim öğretmenlerinin alternatif değerlendirme yöntemlerine yönelik yeterlik düzeyleri. Mehmet Akif Ersoy Üniversitesi Eğitim Bilimleri Enstitüsü Dergisi, 2(2), 26-37. Erişim adresi: https://dergipark.org.tr/en/download/article-file/207766

Eisner, E. (1997). Educating artistic vision. New York: Macmillon.

Er, Ö. (2018). Fen ve teknoloji dersi 7. sınıf ışık ünitesinde alternatif dĕgerlendirme yaklaşımları temelli öğretimin ögrencilerin akademik başarıları ve tutumları üzerine etkisi (Doktora tezi). YÖK Tez veri tabanından erişildi. (Tez No. 503615)

Gelbal, S., \& Kelecioğlu, H. (2007). Öğretmenlerin ölçme ve değerlendirme yöntemleri hakkındaki yeterlik algıları ve karşılaştıkları sorunlar. Hacettepe Üniversitesi Ĕ̆itim Fakültesi Dergisi, 33, 135-145. Erişim adresi: https://dergipark.org.tr/tr/download/article-file/87640

Gill, D., \& Lucas, D. (2013). Using alternative assessment in business and foreign language classes. Journal of International Education Research, 9(4), 359-370. Erişim adresi: https://clutejournals.com/index.php/JIER/ article/download/8088/8141/

Güneş, T., Dilek, N. Ş., Hoplan, M., Çelikoğlu, M., \& Demir, E. S. (2010). Öğretmenlerin alternatif değerlendirme konusundaki görüşleri ve yaptıkları uygulamalar. International Conference on New Trends in Education and Their Implications (s. 925-935) içinde. Antalya: ICONTE. Erişim adresi: http://www.iconte.org/FileUpload/ ks59689/File/204.pdf

Herman, J. L., Klein, D. C., \& Wakai, S. T. (1997). American students' perspectives on alternative assessment: Do they know it's different?. Assessment in Education. 4(3), 339-351. doi: https://doi.org/10.1080/0969594970040302

Huff, S. (2006). Teachers' perceptions of the teacher portfolio process (Doctoral Dissertation). New York: State University of New York at Buffalo. Erişim adresi: http://proquest.umi.com/pqdlink?Ver=1\&Exp=05232014 $\& \mathrm{FMT}=7 \& \mathrm{DID}=1126788031 \& \mathrm{RQT}=309 \&$ attempt $=1 \& \mathrm{cfc}=1$ 
İzci, E., Göktaş, Ö., \& Şad, S. N. (2014). Öğretmen adaylarının alternatif ölçme değerlendirmeye ilişkin görüşleri ve yeterlilik algıları. Journal of Kırsehir Education Faculty, 15(2), 37-57. Erişim adresi: http://kefad2.ahievran.edu.tr/archieve/pdfler/Cilt15Sayi2/JKEF_15_2_2014_37-57.pdf

Karamustafaoğlu, S., Çağlak, A., \& Meşeci, B. (2012). Alternatif ölçme değerlendirme araçlarına ilişkin sınıf öğretmenlerinin öz yeterlilikleri. Amasya Üniversitesi Eğitim Fakültesi Dergisi, 1(2), 167-179. Erişim adresi: https://dergipark.org.tr/tr/download/article-file/19598

Kilmen, S., \& ve Kösterelioğlu, İ. (2017). Öğretmenlerin tamamlayıcı değerlendirme yaklaşımlarına yönelik görüşlerinin CHAID analizi ile incelenmesi. Elementary Education Online, 16(1), 256-273. doi: http://dx.doi.org/10.17051/io.2017.50454

Ling, M. K. (2016). The use of academic portfolio in the learning and assessment of physicsstudents from a Singapore Private College. International Journal of Assessment Tools in Education, 3(2), 151-160. doi: http://dx.doi.org/10.21449/ijate.245199

Llewellyn, D. (2002). Inquire within: implementing inquiry-based science standards. California: Corwinn Press.

Mamur, N. (2009). Anadolu güzel sanatlar lisesi resim bölümü öğrencilerinin sanatsal yeterliliğini ölçme ve değerlendirmede EGD’nin (portfolyo) rolü (Doktora tezi). YÖK Tez veri tabanından erişildi. (Tez No. 227874)

Mamur, N. (2010). Görsel sanatlar eğitiminde ölçme ve değerlendirme. Pamukkale Üniversitesi Ĕ̈itim Fakültesi Dergisi, 28(2). 175-188. Erişim adresi: https://dergipark.org.tr/tr/download/article-file/114623

Mohamed, R., \& Lebar, O. (2017). Authentic assessment in assessing higher order thinking skills. International Journal of Academic Research in Business and Social Sciences, 7(2), 466-476. doi: http://dx.doi.org/10.6007/ IJARBSS/v7-i2/2021

Mojavezi, A. \& Tamiz, M.P. (2012). The impact of teacher self-efficacy on the student's motivation and achievement. Theory and Practice in Language Studies, 2(3), 483-491. doi: http://dx.doi.org/10.4304/tpls. 2.3.483-491

Oliver, E. (2015). Alternative assessment to enhance theological education. HTS Teologiese Studies/Theological Studies. 71(3), 1-10. doi: http://dx.doi.org/10.4102/hts.v71i3.3002

Oluk Turan, N., \& Ekmekci, G. (2017). Comparison of alternative assessment techniques with traditional techniques in terms of measurement of student success. Eğitim ve Toplum Araştırmaları Dergisi, 4(2), 172199. Erişim adresi: https://dergipark.org.tr/tr/download/article-file/393937

Ozan, C. (2019). The effect of authentic assessment on academic achievement and attitude towards educational measurement and opinions of prospective teachers. International Journal of Evaluation and Research in Education (IJERE), 8(2), 299-312. doi: http://dx.doi.org/10.11591/ijere.v8i2.18564

Rivas, M. R., \& Arrufat, M. J. G. (2016). University students' perceptions of electronic rubric-based assessment. Digital Education Review, 30(1), 220-233. doi: https://doi.org/10.1344/der.2016.30.220-233

Sewagegn, A. A., \& Diale, M. B. (2020). Authentic assessment as a tool to enhance student learning in a higher education institution:Implication for student competency. E. Railean (Ed.), Practical Implementation of assessment activities for deep learning (s. 256-271) içinde. USA: IGI Global Reference Books.

Sezer, S. (2005). Öğrencinin akademik başarısının belirlenmesinde tamamlayıcı değerlendirme aracı olarak rubrik kullanımı üzerinde bir araştırma. Pamukkale Üniversitesi Eğitim Fakültesi Dergisi. 18(18), 61-69. Erişim adresi: https://dergipark.org.tr/tr/download/article-file/114756

Şahin, M., \& Atasoy, E. (2018). Sosyal bilgiler öğretmenlerinin alternatif ölçme-değerlendirme yöntemlerine yönelik tutumlarının değerlendirilmesi. Uşak Üniversitesi Eğitim Araştırmaları Dergisi, 4(1), 18-33. doi: https://doi.org/10.29065/usakead.346287

Tekin, H. (2019). Eğitimde ölçme ve değerlendirme. Ankara: Yarg1 Kitap ve Yayınevi.

Walker, J. (1998). Process portfolios as a means for formative and summative evaluation of student work in the visual arts. Paper Presented at the Annual Meeting of the Mid-Western Educational Research Association. Chicago.

Yapıc1, M., \& Demirdelen, C. (2007). İlköğretim 4. sınıf programına ilişkin öğretmen görüşleri. İlköğretim Online 6(2), 204-212. Erişim adresi: http://ilkogretim-online.org.tr/index.php/io/article/download/1920/1756

Yurdakul, B. (2004). Yapılandırmacı öğrenme yaklaşımı öğrenenlerin problem çözme becerilerine, bilişötesi farkındalık ve derse yönelik tutum düzeylerine etkisi ile ögrenme sürecine katkısı (Doktora Tezi). YÖK Tez veri tabanından erişildi. (Tez No. 144332) 